\title{
Yeats and Modernism
}

\section{Citation}

Albright, Daniel. 2006. Yeats and Modernism. In The Cambridge Companion to W.B. Yeats, ed. Marjorie Howes and John Kelly, 59-76. Cambridge: Cambridge Univ. Press.

\section{Published Version}

http://dx.doi.org/10.1017/CCOL0521650895.004

\section{Permanent link}

http://nrs.harvard.edu/urn-3:HUL.InstRepos:3355449

\section{Terms of Use}

This article was downloaded from Harvard University's DASH repository, and is made available under the terms and conditions applicable to Other Posted Material, as set forth at http:// nrs.harvard.edu/urn-3:HUL.InstRepos:dash.current.terms-of-use\#LAA

\section{Share Your Story}

The Harvard community has made this article openly available.

Please share how this access benefits you. Submit a story.

\section{Accessibility}


Published in The Cambridge Companion to W. B. Yeats, eds. Marjorie Howes and John Kelly, 2006.

Daniel Albright

\section{Yeats and Modernism}

When Yeats died in January 1939, he quickly became the ghost that haunted Modernism. First to register the shade's presence was W. H. Auden, who wrote his famous elegy "In Memory of W. B. Yeats" in February 1939:

Now he is scattered among a hundred cities

And wholly given over to unfamiliar affections [ . . ]

The words of a dead man

Are modified in the guts of the living. [...]

For Auden, Yeats is a distasteful Orpheus, whose corpse dismembers into the scattered leaves of his volumes of poetry, undergoing a queasy process of digestion in the guts of his readers.

Auden gives the distinct impression that Yeats might have been a much more satisfactory meal:

You were silly like us [...]

[Time] Worships language and forgives

Everyone by whom it lives;

Pardons cowardice, conceit,

Lays its honours at their feet.

Time that with this strange excuse

Pardoned Kipling and his views,

And will pardon Paul Claudel,

Pardons them for writing well. ${ }^{1}$

He does not directly call Yeats a timid, vain, blustering fascist, but by treating Kipling, Claudel, and unspecified cowardly and conceited poets as parallel cases, he leaves such characterizations open as a possibility.

In an essay in Partisan Review (Spring 1939), "The Public v. the Late Mr. William Butler Yeats," Auden, wearing the mask of the "Public Prosecutor," goes further: he says that Yeats did nothing to "create a juster social order, he felt nothing but the hatred which is born of fear":

Of all the modes of self-evasion open to the well-to-do, Nationalism is the easiest and the most dishonest. [...] Still, it has often inspired men and women to acts of heroism and self-sacrifice. For the sake of a free Ireland the poet Pearse and the countess Markiewicz gave their all. But if the deceased did give himself to this movement, he did so with a 
singular moderation. [. . .] What are we to say of man whose earliest writings attempted to revive a belief in fairies and whose favourite themes were legends of barbaric heroes with unpronounceable names, work which has been aptly and wittily descried as Chaff about Bran? ${ }^{2}$

The defense attorney in Auden's imaginary debate tries a few mild rebuttals of these points, but with less verve and conviction. In 1939 Auden saw Yeats's ghost as a fussy and inept spectre, and yet (as the elegy suggests in a slightly noncommittal fashion) a figure of astonishing force, a river, a fountain in the heart's desert, a whole modality of event; even the bland glance at the thermometer at the opening ("O $\mathrm{O}$ all the instruments agree / The day of his death was a dark cold day") can be interpreted either as the sign of a preference for objective fact over mythy nonsense, or as the symptom of desolation of the landscape from the master's death, as if Yeats were the Grail King from Eliot's The Waste Land. It is impossible to get a clear fix on Auden's attitude toward Yeats; one may feel that Auden scribbles mustaches on Yeats's face to defend himself from Yeats's overwhelming cultural authority. The whole elegy works at once to manifest Yeats's ghost and to exorcise it: even Auden's adoption, in the last part of the poem, of Yeats's almost-patented form of catalectic trochaic tetrameter suggests the power of the ghost to usurp the soul of his elegist. Auden ridicules Yeats's spooks, but seems determined to become a spiritmedium in spite of himself. Because "Under Ben Bulben," Yeats's tetrameter elegy to himself, was not published until February 1939, and then only in three Irish newspapers, the literary historian may feel a certain shiver that the ghost was trying to show itself forth simultaneously through the Irish Times and through Auden's empathic intelligence.

The ghost's next important apparition occurred around August 1942, when T. S. Eliot was writing drafts for the so-far unsatisfactory second part of "Little Gidding":

Then, changing face and accent, he declared with another voice:

These events draw me back to the streets of the speech I learned early in life. I also was engaged in the battle of language. My alien people with an unknown tongue claimed me. I saved them by my effortsyou by my example: yet while I fought the darkness I also fought the light, striving against those who with the false condemned the true. 
Those who have known purgatory

here know it hereafter-so shall you

learn when enveloped by the coils

of the fiery wind, in which you

must learn to swim. ${ }^{3}$

The ghost goes on to say that his "spirit parted from the southern shore"-Yeats died in the south of France-and to add other details that tend to identify him with Yeats, though Yeats's name never appears. As air-raid warden Eliot moves through the dismantled streets of London, he seems to inhabit a purgatory that contains one and only one shade, as if Tradition had fined itself down to a sole Individual Talent, that of Yeats. Like Auden, Eliot seems eager to deface the mighty ghost: Eliot makes him confess that he fought the light as well as the darkness, as if his anarchic strength were so great that nothing whatever, good or bad, could stand before him. In The Waste Land Eliot imagined a Thunder Word, $D A$, an utterance of such force that it might restore vitality to a slack exhausted culture; in "Little Gidding" Eliot imagines a Thunder Speaker, a furious wraith who seems to energize and to destroy; to prophesy and to lacerate; to sustain, even if that sustenance has the bitter taste of shadow fruit. The ghost seems an abstract of the whole culture of the English language, in all its triumph and failure.

In both Auden's poem and Eliot's, the ghost is so intimate with the elegist that every excoriation of the ghost seems a form of self-excoriation. As Auden wrote many years later, Yeats "has become for me a symbol of my own devil of inauthenticity [ . . his poems] make me whore after lies." ${ }^{4}$ This almost repeats Eliot's complaint that Yeats's “"supernatural world' was the wrong supernatural world. It was not a world of spiritual significance, not a world of real Good and Evil, of holiness or sin, but a highly sophisticated lower mythology summoned, like a physician, to supply the fading pulse of poetry with some transient stimulant so that the dying patient may utter his last words." For Auden and Eliot, Yeats was false: he wrote potent, unforgettable poetry without caring whether the content were good or evil, truth or error. In the elegy Auden calls him "A way of happening, a mouth," a line that may insinuate that Yeats was all mouth and no brain, a blank megaphone, the decadents' poésie pure incarnate. Still, he looms.

What Harold Bloom calls the anxiety of influence usually leads to a more elegant and subtle subversion of the great father-poet than this hectoring of Yeats. Auden and Eliot seem to see themselves as walking in Yeats's footsteps, just as Chaucer, at the end of Troilus and Criseyde (1382-86), asks his "litel book" to "kis the steppes where as thow seest pace / Virgile, 
Ovide, Omer, Lucan, and Stace." But Auden and Eliot seem to find themselves confronted with a path that leads straight to purgatory, if not to hell. Has poetry itself, in a dying culture, simply become a form of lying?-the extraordinary prosiness of Auden's and Eliot's later works might suggest that with Yeats the art of poetry has reached its end.

But perhaps Yeats could stimulate his successors precisely because his rhetorical vehemence seemed disconnected from any discipline except the discipline of poetic form. If he struck Auden and Eliot as amoral, evasive, indifferent to truth, he nevertheless reminded them that poetry is incantation, spell, charm-an art dedicated not to correctness but to power. Auden and Eliot were suspicious of the poet's archaic and magical aspect-Auden once wrote thst the purpose of poetry is "by telling the truth, to disenchant and disintoxicate." But it is impossible to disenchant without some prior enchantment, and it may be that Yeats and his drabber Mugglesuccessors form a single whole. The long tradition of British poets, from the savage bards who could make trees walk by casting spells, to the refined sorcery of Yeats, may find its complement and antidote in the later Modernism of Eliot and Auden. But perhaps disillusionment is itself a flattering illusion, and the poet who whores after lies may not always go in the wrong direction.

According to my records, the third visitation of Yeats's ghost occurred in 1945, in a detention camp in Pisa:

I recalled the noise in the chimney as it were the wind in the chimney but was in reality Uncle William downstairs composing that had made a great Peeeacock in the proide ov his oiye made a great peacock had made a great peeeeeeecock in the... in the proide of his oyyee

proide ov his oy-ee as indeed he had, and perdurable a great peacock aere perennius ${ }^{7}$

In this passage from Ezra Pound's Canto LXXXIII, memories of Yeats seem to intensify into a sort of clairaudience. Pound recalls a moment from the winter of 1913-14, when he and Yeats lived in a cottage in Sussex learning craft from one another: Yeats was bawling his poem "The 
Peacock" out loud, to test its cadences as he invented it. Now, in 1945, the finished poem disarticulates itself into wind, pneuma, sheer inspiration. Yeats's organ seems to fill vast spaces with sound, as if he, so intimate with transcendence, had become after death the voice of imagination itself.

For Yeats's successors, then, Yeats was both god and idol, the ark of the covenant and the golden calf.

If Yeats became a ghost that haunted Modernism, Modernism was also a ghost that haunted Yeats. Yeats often casts himself as the enemy of Modernism: if Eliot condemns Romanticism as "fragmentary [ . . ] immature [ . . ] chaotic," "Yeats asserts "We were the last romantics"; and again and again Yeats flogs the Modernist poets for their sloppiness of construction ("All out of shape from toe to top"10) and flatness of diction. He never pretends to understand the concept of free verse; the best that he can say of an ametrical poem that he finds reasonably attractive, Pound's "The Return," was that it seems like a brilliant improvisation that "has not got all the wine into the bowl."11 When, in the Introduction to The Oxford Book of Modern Verse (1936), the elderly Yeats sums up his response to contemporary poetry, he finds a writhe, a seethe, a degenerate mess: "Nature, steel-bound or stone-built in the nineteenth century, became a flux where man drowned or swam; the moment had come for some poet to cry 'the flux is in my own mind." "'12 Most of all Yeats despises the absence of metaphor, the dead plod, in advanced recent poetry: he even offers a little caricature of a Modernist poem, "It has sometimes seemed of late years [ . . ] as if the poet could at any moment write a poem by recording the fortuitous scene or thought, perhaps it might be enough to put into some fashionable rhythm-'I am sitting in a chair, there are three dead flies on a corner of the ceiling." ${ }^{\prime 13}$ As Yeats says elsewhere, this rejection of imagination reminds him of the sedate bewigged poetry of the Augustan age: "Technically we are in a state corresponding to the time of Dryden [. . . We are developing a poetry of statement as against the old metaphor. The poetry of to-morrow will be finely articulated fact. T. S. Eliot fascinates us all because he is further on towards this consummation than any other writer." ${ }^{" 14}$ It seems that Modernist poetry paradoxically combines all the worst aspects of triviality and incomprehensibility.

And yet, one might venture to argue that there is not a single feature that Yeats ascribes to Modernist poetry that cannot be found in Yeats's own poetry. Vulgar diction starts to intrude 
in the late 1930s: "His rod and its butting head / Limp as a worm"; "Belly, shoulder, bum, / Flash fishlike." 15 Much earlier, at the time of his winters in Sussex with Pound, there come experiments with something like free verse. Compare Pound's "The Return" with a passage from Yeats's play At the Hawk's Well:

See, they return, one, and by one, With fear, as half-awakened; As if the snow should hesitate

And murmur in the wind, and half turn back; ${ }^{16}$

Her heavy eyes

Know nothing, or but look upon stone.

The wind that blows out to sea

Turns over the heaped-up leaves at her side;

They rustle and diminish. ${ }^{17}$

It is difficult to find any technical reason for declaring one passage freer than the other: each has irregular line lengths, and an iambic pulse unsteadied by extra syllables in odd positions; if anything, more wine spills out of Yeats's bowl than Pound's. As for Modernist fortuitousness, dependency on casual observation, we can even find a Yeats poem not far removed from "I am sitting in a chair, there are three dead flies on a corner of the ceiling":

The bees build in the crevices

Of loosening masonry, and there

The mother birds bring grubs and flies.

My wall is loosening, ${ }^{18}$

This is a somewhat unfair example, since Yeats instantly proceeds to take the scenery as a metaphor for his spiritual state, and the stanza concludes with a prayer:

$$
\text { honey-bees, }
$$

Come build in the empty house of the stare.

On the other hand, might not the imaginary Modernist poet have meant the three dead flies as an emblem of despondency, torpor? Does not Yeats himself mean to say something about the inner life of Modernism by referring to the three dead flies?

One aspect of bold artistic ambition is the desire to be complete; and Yeats may have felt, consciously or unconsciously, that he had to incorporate the methods and themes of Modernism in order to comprehend in himself the whole round of art. Similarly Igor Stravinsky, in old age, 
fitfully abandoned his tonal style and adopted an idiosyncratic version of Arnold Schoenberg's twelve-tone methods. Stravinsky waited until Schoenberg's death in 1951 before attempting something that might be read as capitulation; Yeats, however, did not have the luxury of trying to outlive Pound, Eliot, and Auden, and so had to fight them and to accommodate them at the same time.

Many of those whom we call the High Modernists were born in the 1880s: Ludwig Kirchner, Pablo Picasso, Stravinsky, Béla Bartók, Virginia Woolf, Anton Webern, James Joyce, D. H. Lawrence, Pound, Alban Berg, and Eliot, for example. Yeats was born in 1865, during a decade far less richly productive of English writers; but if we look beyond the confines of English literature, we find in the 1860s the birthyears of a number of important Modernists, or precursors to Modernism, such as Claude Debussy, Gustav Klimt, Richard Strauss, Vassily Kandinsky, and Henri Matisse. All of them were profoundly influenced by the aesthetic of Symbolism, the artistic movement that leads most directly into Modernism.

Accounts of the origin of Modernism often begin with Charles Baudelaire, partly because Baudelaire's The Painter of Modern Life (1864) gave such prestige to the term modern: this solitary mortal endowed with an active imagination, always roaming the great desert of men [...] is looking for that indefinable something we may be allowed to call "modernity," for want of a better term to express the idea in question. The aim for him is to extract from fashion the poetry that resides in its historical envelope, to distil the eternal from the transitory. [.. .] Modernity is the transient, the fleeting, the contingent; it is one half of art, the other being the eternal and the immovable. [...] You have no right to despise this transitory fleeting element, the metamorphoses of which are so frequent, nor to dispense with it. If you do, you inevitably fall into the emptiness of an abstract and indefinable beauty ${ }^{19}$

Of course, if Modernism is defined as the art of fugitive urban junk-posters for last week's cabaret singers ungluing in the rain, orange peels flushing into the sewers-Yeats is the least Modernist of poets. Many Modernists were at home in cities; one rarely encounters a major character in a novel by Joyce or Woolf who would feel comfortable milking a cow. But Yeats's attitude toward the pavements grey, despite the fact that he lived in Dublin or London for most of his life, was contempt: "When I stand upon O'Connell bridge in the half-light and notice that discordant architecture, all those electric signs, where modern heterogeneity has taken physical form, a vague hatred comes come up out of my own dark."

On the other hand, Baudelaire was also the poet of "Correspondences," which defines 
nature as a temple where living pillars utter confusing words-man passes through a forest of symbols that stare at him with an intimate gaze. This is the sonnet that gave an important push to the Symbolist movement. In fact, the tension in Baudelaire's aesthetic between the "transitory fleeting element" and "abstract and indefinable beauty"-between the city's detritus and transsensuous sanctity-helped to generate Modernism itself. In his occult book A Vision (1925) Yeats expresses this tension as an eternal competition between objective (factual, ugly) and subjective (symbolic, beautiful), continually boring into one another in the peculiar arrangement he called a double gyre-a set of intersecting cones. Yeats feels that the Modernist artists were to some extent failures, in that their work shows a grotesque floundering between realistic and mythic / hallucinatory elements:

Mr Ezra Pound, Mr Eliot, Mr Joyce, Signor Pirandello [. . . ] either eliminate from metaphor the poet's phantasy [. . .] or [. . . break up the logical processes of thought by flooding them with associated ideas or words that seem to drift into the mind by chance; or [. . . ] set side by side as in "Henry IV," "The Waste Land," "Ulysses," the physical primary-a lunatic among his keepers, a man fishing behind a gas works, the vulgarity of a single Dublin day prolonged through 700 pages-and the spiritual primary, delirium, the Fisher King, Ulysses' wandering. It is as though myth and fact [. . .] have now fallen so far $\operatorname{apart}^{21}$

This is not a bad reading of Modernism: a heap of urban garbage weirdly juxtaposed with antique glamour. Professors like to teach Ulysses by stressing the points of connection between Homer's Odyssey and Joyce's novel; but much of the pleasure lies in the bitonal clash, the discord between the two texts.

From a Symbolist point of view-from Yeats's point of view-the objective or realistic elements exist only as a sort of colorful wrapping paper that half-disguises, half-reveals, the bright ineffabilities within. As Thomas Carlyle put it in 1836, man's “Life is properly the bodying forth" of the Invisible, and "In a Symbol there is concealment and yet revelation"22.; as Jean Moréas put it in the Symbolist manifesto of 1886,

Symbolic poetry, the enemy of "instruction, declamation, false sensibility, and objective description," seeks to clothe the Idea in a tangible form which will not be that poetry's object but which, while serving to express the Idea, will remain subordinate. Nor must the Idea itself be seen stripped of the sumptuous robes of external analogy; for the essential characteristic of symbolic art is never to go so far as the conception of the Idea in itself. Thus, in this art, neither scenes from nature nor human actions nor any other physical phenomena can be present in themselves: what we have instead are perceptible appearances designed to represent their esoteric affinities with primordial Ideas. $^{23}$ 
Symbolist art, then, is an aesthetic of strip-tease, an unveiling of something (intense, devastating) that can never be shown quite naked, lest the spectator, like Semele, perish from overapprehension. This explains why the Symbolists keep reviving again and again the story of Salome (who never had a dance of the seven veils until Oscar Wilde provided her with one in his 1893 play): Richard Strauss in his 1905 opera; Yeats in the story "The Binding of the Hair" (1896) and the plays The King of the Great Clock Tower (1934) and A Full Moon in March (1935); and Klimt in his 1901 Judith (presumably the severed head belongs to Holofernes, not John the Baptist, but the woman's eyes-half-shut, head-thrown-back, lips-faintly-parted look of sexual languor tends to make the spectator think first of Salome). The art work becomes the garment of shimmering gold, the erogenous zone beneath which some bulge of meaning makes itself felt.

Yeats is always happier with symbols drawn from the traditional stock of conventions than with symbols drawn from modern life. For Yeats, such fact-scenes as a man fishing behind the gas works could never align themselves properly with a myth, a meaning-so The Waste Land looks to him like a bunch of industrial photographs arbitrarily pasted onto the story of Parsifal or Adonis, like a tin can tied to a dog's tail. It took a later generation of Modernists to savor the dissonance between fact and myth with full appreciation of the aesthetic possibilities. Nevertheless Yeats's works, like those of all the Symbolists, are full of the most up-to-date references, though the contemporaneity is sometimes occluded. The Viennese public that first saw Klimt's Judith regarded it as a disturbing portrait of a contemporary upper-class Jewish woman, and Klimt's exceedingly volumeless, intricate style reflects the most recent artistic trends; Strauss's music characterizes Salome as a creature of pure chromatic glitz, sometimes slithering out of tonality altogether; and Yeats furnishes his play The King of the Great Clock Tower with the movable abstract sets that the visionary director Gordon Craig had devised for a famous early-twentieth-century production of Dido and Aeneas: "an inner curtain [. . .] may have a stenciled pattern of dancers . [. . . one sees to left the King and Queen upon two thrones, which may be two cubes. There should be two cubes upon the opposite side to balance them. [. . .] The background may be a curtain hung in [. . .] a semi-circle of one foot Craig screens, so painted that the blue is darker below than above."24 Yeats aspires to a sort of timelessness, but the conventions of his eternity are those determined by the Cubism of Picasso and the 
dramaturgy of the Noh play as revealed by a Japanese dancer who had studied with the Denishawn modern dance company in New York. Another sign of Yeats's engrossment with Modernist abstraction can be found in his last play, The Death of Cuchulain, in which Cuchulain's severed head is represented by “a black parallelogram, the size of a man's head. There are six other parallelograms near the backcloth." 25 The more fervently Yeats tries to disencumber himself of the modern world, the more deeply the modern world imprints itself upon his work.

The first aesthetic movement fully to rejoice in the technological present-and in that sense the first Modernist movement-thrust itself on Europe in 1909, when Filippo Tommaso Marinetti published his Futurist manifesto in Le Figaro. For Baudelaire, the city was a zone of detachment, where a distinguished, nearly extinguished observer could gaze into shop windows, or contemplate a spectral throng of passing strangers; for Marinetti, the city was a zone of power, the buzzsaw of motors on the street, the silent buzz of electric wires above, an outspew of signifiers. For Marinetti, an art work should aspire to the brute certainty of the laws of physics: "To substitute for human psychology, now exhausted, the lyric obsession with matter. [...] The warmth of a piece of iron or wood is in our opinion more impassioned than the smile or tears of a woman." 26 Furthermore, art should attune itself to the radiation that permeates the universe-as he wrote, collaborating with some Futurist painters, in the "Technical Manifesto of Futurist Painting": "All things move, all things run, all things are rapidly changing. [ . . ] moving objects constantly multiply themselves: their form changes, like rapid vibrations, in their mad career. Thus a running horse has not four legs but twenty [. . . Who can still believe in the opacity of bodies, since our sharpened and multiplied sensitivity has already penetrated the obscure manifestations of the medium? Why should we forget in our creations the doubled power of our sight, capable of giving results analogous to those of X-rays?"27

Yeats, of course, detests most of the things that Marinetti loved. He purges his poetic vocabulary of technological words; as he explains to Virginia Woolf, such words as steamroller were altogether dead to his ear: "He said that the spade had been embalmed by 30 centuries of association; not so the steam roller. The great age of poetry, Shakespeare's age, was subjective; ours is objective; civilisations end when they become objectified. Poets can only write when they have symbols. And steam rollers are not covered in symbolism-perhaps they may be after 
30 generations. ${ }^{28}$ For Marinetti, the shock, the crush, imparts to the steamroller the most potent symbolic value, while the spade has long since sunk into the realm of the boring; for Yeats, symbolic value can be imparted only by age and long use-no word is fit for poetry unless your great-grandfather uttered it.

And yet, Yeats is fascinated by what he loathes, and technology, obliquely or directly, makes a strong appearance in his writing. Aerial warfare especially haunts him, from the symbolical "brazen hawks" whose "innumerable clanging wings that have put out the moon" to the quite explicit evocation, "Aeroplane and Zeppelin will come out, / Pitch like King Billy bomb-balls in." ${ }^{29}$ A canceled passage from "Under Ben Bulben," also on the theme of aerial bombardment, shows Yeats's closest approach to Futurism:

So what's the odds if war must come

From Moscow, from Berlin, or Rome.

Let children should an aeroplane

Some neighbouring city pavement stain,

Or Should the deafening cannon sound

Clasp their hands \& dance in a round.

The passing moment makes it sweet

When male \& female organ meet ${ }^{30}$

The poem cuts from exploding bombs to dancing children to orgasm. Marinetti wrote odes to his femme fatale the machine gun; Yeats here toys with a similar confusion of the erotic and technological. Yeats's great-grandfather surely never used the word aeroplane; and yet a device that can provoke such powerful glee may indeed be fit for use in a poem.

Even the robot, that science-fiction gadget familiar from Karel ,apek's R.U.R. (1921) and Fritz Lang's film Metropolis (1927), has a role to play in Yeats's imagination. Ezra Pound, in his more demonic aspect, could appear to Yeats as a big doll or robot: "Mr. Pound, not transfigured but transfixed contemplat[ing] the race [ . . . until hatred turns the flesh to wood and the nerves to wire. ${ }^{, 31}$ And when Yeats considers the future society of A.D. 2000-the end of our modern thing-driven, fact-ridden civilization, according to his historical system-he has a vision of gigantic puppets chomping or manipulating small human figures:

with the last gyre must come a desire to be ruled or rather, seeing that desire is all but dead, an adoration of force spiritual or physical, and society as mechanical force be complete at last. 
Constrained, arraigned, baffled, bent and unbent

By those wire-jointed jaws and limbs of wood

Themselves obedient,

Knowing not evil and good.

A decadence will descend [...] what awaits us, being democratic and primary, may suggest bubbles in a frozen pond-mathematical Babylonian starlight. ${ }^{32}$

Technology may be Moloch, a general smashing or petrifying of things, but it does not lack poetic interest.

The machine is exceedingly sinister in Yeats's work, as his version of a mock mechanical Creation suggests:

Locke sank into a swoon;

The Garden died;

God took the spinning-jenny

Out of his side. ${ }^{33}$

Yeats discovers the gynoid not only in the spinning-jenny but also in The Waste Land's typist, whose verse-movement seems to him as mechanical as the gramophone she plays "with automatic hand": "in The Waste Land there is much monotony of accent." machines, he likes electromagnetic radiation just as much as the Futurists did. Giacomo Balla painted objects that decompose into fields of force (Street Lamp 1909); Luigi Russolo painted objects generated from the vibration-patterns of sound (Music, 1912). If Yeats, following Blake, rejects the Newtonian model of the clockwork cosmos in which dead objects swing inexorably around other dead objects, Yeats hopes that post-Newtonian physics may be far more congenialmay even find experimental proof for the existence of the phenomena he witnesses during spiritualist séances:

I once heard Sir William Crookes tell half a dozen people that he had seen a flower carried in broad daylight slowly across the room by what seemed an invisible hand. His chemical research led to the discovery of radiant matter, but the science that shapes opinion has ignored his other research that seems to those who study it the slow preparation for the greatest, perhaps the most dangerous, revolution in thought Europe has seen since the Renaissance, a revolution that may, perhaps, establish the scientific complement of certain philosophies that in all ancient countries sustained heroic art. ${ }^{35}$

Crookes was the physicist who developed the cathode ray tube, by sending an electric current through rarefied air; the "radiant matter" mentioned by Yeats has nothing to do with radioactivity, but instead refers to a fourth state of matter, beyond solid, liquid, or gas, that Crookes (incorrectly) described. Crookes noticed that cathode rays caused certain substances to 
phosphoresce; and it seemed to Yeats that Crookes' scientific and psychic researches were converging-that ectoplasm was receiving a sort of public confirmation. Marinetti looked forward to an art of pure radiation: "The reception amplification and transfiguration of vibrations emitted by matter Just as today we listen to the song of the forest and the sea so tomorrow shall we be seduced by the vibrations of a diamond or a flower." ${ }^{36}$ It is of course a long way from Madame Blavatsky to Marconi, and yet both Yeats and Marinetti hope for a poetry in which potent vibrations far beyond the visible spectrum would enter into the field of knowing.

During and just after the Great War, starting in the cabarets of Zurich and Berlin, the Modernist movement stared directly at its limits. How far could art go toward a radical attack on the assumptions that governed its own operation and reception? How far could art go toward a disengagment of itself from history, from canons of beauty, from the human mind itself? Here, in the world of Dada, artists performed experiments in dismembering art: Tristan Tzara, for example, generated poems by cutting up newsprint into individual words, mixing them in a hat, and pulling them out one by one. Here is the art that Yeats sets himself against, "All out of shape from toe to top"-indeed it had no purpose except to investigate the aesthetics of out-ofshape. And yet, from a certain point of view, the Dadaists were behaving like magicians, who have always looked for inspiration to random designs, the pattern of dregs in the bottom of teacups, the flight of birds, the twist of intestines, a word chosen by chance from Virgil or the Bible. Yeats's magic was purposive and consequential, unlike the magic of the Dadaists, but they were alike hoping for revelation from disordered fields or from the null set.

According to the mythology of Yeats's A Vision, personality types close to the full moon, Phase 15, are lost in imaginative reverie, while personality types close to the new moon, Phase 1, are lost in contemplation of objective truth. Therefore, those personality types that fit into the last few days of the lunar month, Phases 26, 27, and 28, lead useful lives only insofar as they try to cure themselves of desire, try to accept the physical world exactly as it is. For most of the phases, Yeats lists human exemplars, such as Keats in Phase 14, and Blake (and Maud Gonne) in Phase 16, since Romantic poets and beautiful women manifest the maximum degree of imagination; but for the extremely objective phases, Yeats mentions no specific people, except for Socrates and Pascal in Phase 27, the phase of the Saint-most of those born in these phases have too little personality to leave any trace in the historical record. Abandoned to the sheer 
factuality of things, they cannot register any Gestalten of themselves against the immitigable background of hard objects and hard ideas. And yet, Yeats likes to correlate his phases of human personality with artistic movements; and if I read his descriptions of Phases 26 and 28 correctly, Yeats is thinking of people who might be called Dadaists.

Phase 26 is called the Hunchback, or the Multiple Man:

All the old abstraction, whether of morality or of belief, has now been exhausted [...] there is an attempt to substitute a new abstraction, a simulation of self-expression. [. ..] He is all emphasis, and the greater that emphasis the more does he show himself incapable of emotion, the more does he display his sterility. If he live amid a theologically minded people, his greatest temptation may be to defy God, to become a Judas who betrays, not for thirty pieces of silver, but that he may call himself creator. [. . .] "The Hunchback is his own Body of Fate.",37

Body of Fate is Yeats's technical term for the objective world as it manifests itself to a particular person. Therefore, the Hunchback has in effect turned into a thing: incapable of having a finite personality, he is simply a deformation, a lump of clay not yet shaped into a man. If Yeats's Hunchback, utterly incoherent and unimaginative, were to become an artist, he could do little more than to exhibit his own falseness by means of spasms of nihilistic defiance. This is one interpretation of what the Dadaists in fact did. In Yeats's play about Judas, Calvary (1920), the Roman soldiers perform a "dance of the dice-throwers" for Christ's cloak, and, in a note to the play, Yeats tells a story about an old Arab who has spent his life worshiping God's Chance: "If I should throw from the dice-box there would be but six possible sides on each of the dice, but when God throws He uses dice that have all numbers and sides." ${ }^{38}$ I know no better description of the God of Dada, the random number generator from whom the universe streams. As Tzara said, "Everything is incoherent [ . . ] There is no logic. [ . . ] The acts of life have no beginning and no end. Everything happens in a completely idiotic way. ${ }^{39}$ If the Hunchback points the way toward identification of the human subject with exterior chaos, Yeats's Fool, at Phase 28, has fully achieved it: "He is but straw blown by the wind, with no mind but the wind and no act but a nameless drifting and turning. ${ }^{40}$ It is as if he were cut up and put inside Tzara's hat.

Of all the radical aspects of Modernism, Surrealism came closest to touching Yeats. By the early 1920s the disintegrating force of Dada had reached such a pitch that it managed to disintegrate itself; and from its orts and scraps André Breton cobbled together a movement which he called, borrowing a term that Apollinaire had coined in 1917, Surrealism. Surrealism can be 
conceived as a pyschologizing of Dada, in that it displaced the locus of random from the exterior universe to the human mind. As Breton defined it in the Surrealist Manifesto, "SURREALISM, n. Pure psychic automatism [. . .] Dictation of thought in the absence of all control exercised by reason."41 Breton experimented with methods for hearing the inspired voice, the dictation of the unconscious, by cultivating states of trance, waiting, at last transcribing the mysterious words and images that appeared. Breton gave a famous example of words that "knocked at the window" of his mind: "There is a man cut in two by the window' [ . . ] it was accompanied by a feeble visual representation of a walking man sliced halfway up by a window perpendicular to this axis of his body."

Breton's automatism had the cachet of Freud and the literary avant-garde. But Yeats was pursuing a surprisingly similar automatism, under the far less reputable aegis of occult research. Yeats records in his autobiography some of his sessions with Macgregor Mathers, a quixotic, war-obsessed visionary: when Yeats closed his eyes and Mathers held a cardboard symbol to Yeats's head, "there arose before me mental images that I could not control: a desert and black Titan raising himself up by his two hands from the middle of a heap of ancient ruins. Mathers explained that I had seen a being of the order of Salamanders because he had shown me their symbol."43 In this light, Yeats's poem "The Second Coming" (1920) looks like a transcript of an automatic process of image-evocation: the poet empties his mind until it becomes a tabula rasa; then in the blank desert there appear complicated intra-ocular effects ("Reel shadows of the indignant desert birds") and in the center a vision, more virtual than actual, of a sphinxAntichrist, slouching "towards Bethlehem to be born." convulsive beauty; and Yeats's poems often record both images of terrible beauty and the processes of imaginative convulsion that bring them into being.

Yeats differs from Breton in that his rigid stanza forms, his extraordinary syntactical control, impose a sort of discipline on the imaginative act. Yet sometimes that very discipline could impose a sense of the automatic. "Sailing to Byzantium" (1927) begins with a leisurely, somewhat loose stanza about Ireland's salmon falls and mackerel-crowded sees, but ends with a stanza in which the poet imagines himself transfigured after death into a golden bird-written in tick-tock iambs, this stanza gives the feel of a key winding the mechanical bird's mainspring. It is a powerful conclusion, this twitter of hammered gold and gold enameling; and yet it verges on a whole world of Modernist toys, as in Stravinsky’s Hans Christian Andersen fable The 
Nightingale (1914)-the artificial nightingale is Stravinsky's true heroine, not the real oneGeorge Antheil's Golden Bird (1921), and Paul Klee's Twittering Machine (1921). One of the sources of Surrealism's force is a certain shivery sense that the voice of the unconscious or transconscious has little of human pertinence to say-that its dictate is something inanimate, vain, a measured seizure, a rote chirp. It makes us uncomfortable to think that deepest oracle may scarcely serve to keep a drowsy emperor awake.

In the last year of his life, when Yeats decrying the out-of-shape-from-toe-to-top as loudly as he could, he was also experimenting more intently than ever before with seriously shapeless ways of writing, as in "High Talk" (1938), a poem about a stilt-walker:

All metaphor, Malachi, stilts and all. A barnacle goose

Far up in the stretches of night; night splits and the dawn breaks loose;

I, through the terrible novelty of light, stalk on, stalk on;

Those great sea-horses bare their teeth and laugh at the dawn. ${ }^{45}$

Yeats does not quite indulge in the slosh of images that André Breton could produce, but he comes close:

Ah, to take a bath, a bath of the Romans, a sand bath, an ass's milk sand bath. [. . .] To travel on the back of a jellyfish, on the surface of the water, then to sink into the depths to get the appetite of blind fish, of blind fish that have the appetite of birds that howl at life. $^{46}$

This passage is from The Immaculate Conception (1930), a text in which Breton tries to find prose equivalents for various mental diseases. As Yeats's speaker admits that he and his world consist entirely of metaphor, he seems to lose any sense of what these tropes are metaphors for: they seem to become free radicals, figures of speech incapable of terminating in meaning, metaphors for nothing in particular, simply constituents of a landscape deliquescing into ecstasy. This is an essentially Surrealist state of referencelessness: barnacles, geese, sea-horses, it is all a pullulation of words, just as Breton's text continually deviates into inconsequence. The recklessness of Yeats's last year can scarcely be exaggerated. Sometimes he casts a cold eye on life and death; other times he undergoes strange seizures of giddiness and frivolity, as when, in his play The Herne's Egg, a man enters “leading a Donkey, a donkey on wheels like a child's toy, but life-size."47 One explanation of the origin of the word dada is that it is a child's word for hobby-horse; Yeats promotes the hobby-horse to a character in an apocalyptic farce.

It could be argued that Yeats's A Vision is the greatest of all Surrealist experiments. 
Based on years and years of George Yeats's trances, in the form of both automatic writing and transcriptions of voices she uttered while she slept, $A$ Vision ever falters in its attempts to rationalize the unrationalizable: the messages from the unconscious, or from beyond death, seem all the eerier because they exercise such strong resistance against interpretation. Breton's texts, by contrast, have a certain stressless feel, because Breton, a trusting man, rarely calls them into question. I have previously quoted some of the passages from $A$ Vision that describe the failure of the human subject to constitute itself before the disorderliness, the defunction of things; perhaps no Modernist text is more intimate with chaos.

The strenuous geometry of $A$ Vision, with its diagrams of gyres and cones and midnight things, does not lessen the feel of chaos's hand at work. Nothing is more formless than arbitrary form: when the form imposed is the wrong form for the content, or when the content is such that any form would be the wrong form, then form does not serve to articulate or illuminate. Yeats deplores the arbitrary form he found in Cubist painting:

I feel in Wyndham Lewis's Cubist pictures an element corresponding to rhetoric arising from his confusion of the abstract with the rhythmical. Rhythm implies a living body, a breast to rise and fall, or limbs that dance, while the abstract is incompatible with life. ${ }^{48}$

And yet, he repeatedly describes $A$ Vision as an essentially Cubist book:

the whole philosophy was so expounded in a series of fragments which only displayed their meaning, like one of those child's pictures which are made up out of separate cubes, when all were put together. ${ }^{49}$

This childishness is not something clumsy and immature, but the high childishness of High Modernism itself:

now that my system stands out clearly in my imagination I regard [the gyres] as stylistic arrangements of experience comparable to the cubes in the drawing of Wyndham Lewis and to the ovoids in the sculpture of Brancusi. ${ }^{50}$

Yeats fights Modernism as hard as he could, only to find himself acknowledging that he was Modernist to the marrow of his bones. But this paradox is itself typical, for the Modernist often travels a road as far as it will go, only to wind up in some exactly opposite place.

\section{Notes}

1. W. H. Auden, The English Auden, ed. Edward Mendelson (New York: Random House, 1977), pp. 242-43. 
2. Ibid, pp. 390-91.

3. Helen Gardner, The Composition of Four Quartets (New York: Oxford University Press, 1978), p. 186.

4. Humphrey Carpenter, W. H. Auden: A Biography (Boston: Houghton Mifflin, 1981), p. 416.

5. T. S. Eliot, After Strange Gods: A Primer of Modern Heresy (New York: Harcourt, Brace, 1933), p. 51.

6. W. H. Auden, The Dyer's Hand (New York: Random House, 1962), p. 27.

7. Ezra Pound, The Cantos of Ezra Pound (New York: New Directions, 1995), p. 553-54.

Horace (Odes 3.30) intended his poems to be aere perennius, more lasting than bronze.

8. T. S. Eliot, Selected Essays (New York: Harcourt, Brace, 1960), p. 15.

9. W. B. Yeats, The Poems, ed. Daniel Albright (London: J. M. Dent, 1994), p. 294.

10. Ibid, p. 375.

11. W. B. Yeats, ed., The Oxford Book of Modern Verse, 1892-1935 (Oxford: Clarendon Press, 1936), p. xxvi.

12. Ibid, p. xxviii.

13. Ibid, pp. xxvii-xxviii.

14. E. H. Mikhail, E. H. W. B. Yeats: Interviews and Recollections (New York: Barnes and Noble Books, 1977), vol. II, p. 200.

15. Yeats, The Poems, pp. 348, 386.

16. Ezra Pound, Personae (New York: New Directions, 1926), p. 74.

17. W. B. Yeats, The Variorum Edition of the Plays of W. B. Yeats, ed. Russell K. Alspach (New York: Macmillan, 1966), p. 401.

18. Yeats, The Poems, p. 250.

19. Modernism: An Anthology of Sources and Documents, ed. Vassiliki Kolocontroni et. al., Chicago: University of Chicago Press, 1998, pp. 106-7. The translator here is P. E. Charvet.

20. W. B. Yeats, Essays and Introductions (New York: Macmillan, 1968), p. 526.

21. W. B. Yeats, A Critical Edition of Yeats's A Vision (1925), ed. G. M. Harper and W. K. Hood 
(New York: Macmillan, 1978), pp. 211-12.

22. Thomas Carlyle, Sartor Resartus (London: J. M. Dent, 1975), pp. 164-65.

23. Cited in Robert L. Delevoy, Symbolists and Symbolism (New York: Rizzoli, 1982), p . 71.

24. Yeats, Variorum Plays, pp. 990, 992.

25. Ibid, p. 1061.

26. Filippo Tommaso Marinetti, Marinetti: Selected Writings, tr. R. W. Flint and Arthur A. Coppotelli (New York: Farrar, Straus and Giroux, 1972), p. 87.

27. Cited in Caroline Tisdall and Angelo Bozzolla, Futurism (New York: Thames and Hudson, 1989), pp. 33, 35.

28. Virginia Woolf, The Diary of Virginia Woolf, Volume III, 1925-1930, ed. Anne Olivier Bell, assisted by Andrew McNeillie (New York: Harcourt Brace Jovanovich, 1980), p. 330

29. Yeats, The Poems, p. 252, 341.

30. Jon Stallworthy, Vision and Revision in Yeats's Last Poems (Oxford: The Clarendon Press, 1969), pp. 163-64.

31. George Mills Harper, The Making of Yeats's 'A Vision': A Study of the Automatic Script, Volume II (Carbondale: Southern Illinois University Press, 1987), p. 28.

32. Yeats, Critical Edition of Yeats's A Vision (1925), p. 213. Yeats here quotes a version of a stanza of his poem "The Double Vision of Michael Robartes."

33. Yeats, The Poems, p. 260.

34. Yeats, Oxford Book of Modern Verse, p. xxi.

35. Yeats, Variorum Plays, p. 569.

36. Filippo Tommaso Marinetti and Pino Masnata, "La radia," tr. Stephen Sartarelli, in Wireless Imagination, ed. Douglas Kahn and Gregory Whitehead (Cambridge: MIT Press, 1992), p. 267.

37. W. B. Yeats, $A$ Vision (New York: Macmillan, 1969), pp. 177-78.

38. Yeats, Variorum Plays, p. 790.

39. Robert Motherwell, ed., The Dada Painters and Poets: An Anthology (Cambridge: Belknap Press, 1981), pp. 250-51.

40. Yeats, A Vision, p. 182. 
41. Breton, Oeuvres complètes, édition établie par Marguerite Bonnet (Paris: Éditions Gallimard, 1988), vol. I, p. 328

42. Ibid, pp. 324-35.

43. W. B. Yeats, The Autobiography of W. B. Yeats (New York: Collier, 1965), p. 125.

44. Yeats, The Poems, p. 235.

45. Ibid, p. 391.

46. André Breton, What is Surrealism? Selected Writings, ed. Franklin Rosemont (New York:

Pathfinder, 1978), p. 50. This passage was translated by John Ashbery.

47. Yeats, Variorum Plays, p. 1014.

48. W. B. Yeats, The Letters of W. B. Yeats, ed. Allan Wade (London: Rupert Hart-Davis, 1954), p. 608 .

49. Yeats, A Critical Edition of Yeats's A Vision (1925), p. 11.

50. Yeats, A Vision, p. 25. 